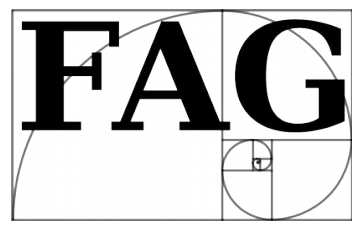

Filozoficzne Aspekty Genezy - 2014, t. 11

Philosophical Aspects of Origin

s. $133-149$

http://www.nauka-a-religia.uz.zgora.pl/images/FAG/2014.t.11/art.05.pdf

Bruce L. Gordon

\title{
W obronie uniformitaryzmu *
}

Naukę uprawia się $w$ zgodzie z założeniem niezawodnej regularności zjawisk świata fizycznego. Przyjmuje się, że świat ma strukturę przyczynowa, która można badać i rzetelnie poznać za pośrednictwem eksperymentów, obserwacji $i$ hipotez naukowych. Co do tego nie ma watpliwości. Pozostaje jednak problem uzasadnienia - zasadniczego dla heurystycznej użyteczności nauki - metafizycznego i metodologicznego założenia, że przyroda jest jednostajna, dzięki czemu teraźniejszość może być kluczem do przeszłości i przyszłości. W niniejszym artykule główna uwagę poświęca się metafizycznej podstawie i uzasadnieniu przyjętych w uniformitaryzmie założeń dotyczacych przyrody oraz wykazaniu, że sq one niezgodne tak z metafizyczna, jak i metodologiczna odmiana naturalizmu. ${ }^{1}$

*Bruce L. Gordon, „In Defense of Uniformitarianism”, Perspectives on Science and Christian Faith 2013, vol. 65, no. 2, s. 79-86, http://www.asa3.org/ASA/PSCF/2013/PSCF6-13Gordon. pdf (28.02.2014). Za zgodą Autora i Redakcji z języka angielskiego przełożyli: Agnieszka BIEsiadecka, Dorota Brylla, Małgorzata Gazda, Grzegorz Malec, Radosław Plato, Maciej PowąsKa, Alicja Ratajczak i Dariusz Sagan. Przekładu dokonali studenci filozofii na Uniwersytecie Zielonogórskim w ramach translatorium z języka angielskiego, prowadzonego przez dra Dariusza Sagana oraz doktorantów z Instytutu Filozofii Uniwersytetu Zielonogórskiego.

${ }^{1} \mathrm{Z}$ obszerniejszą i inaczej zorientowaną obroną poglądu o metafizycznej i poznawczej konieczności teizmu jako podstawy praktyki naukowej można zapoznać się w najnowszej książce Alvina Plantingi, Where the Conflict Really Lies: Science, Religion, and Naturalism, Oxford University Press, New York 2011. Plantinga argumentuje, że chociaż w historii interakcji oraz obecnym wzajemnym stosunku nauki i teizmu dostrzegalne są powierzchowny konflikt i glęboka zgodność, to jednak między nauką a naturalizmem metafizycznym panują powierzchowna zgodność i bardzo glęboki konflikt. Zgadzam się z tym w zupełności. Głęboki epistemologiczny konflikt między nauką a naturalizmem ujawnia się szczególnie w kontekście teorii ewolucji i jej naturalistycznych konsekwencji dla wiarygodności ludzkiego poznania, a te konsekwencje rozciągają się nie tylko na naukę, lecz na każdą działalność człowieka. 
Zacznijmy od ustaleń terminologicznych. W niniejszym artykule „naturalizm” to termin filozoficzny, a „naturaliści” to nie badacze przyrody, lecz ci, którzy utrzymują określone przekonania na jej temat. W szczególności, według naturalistów metafizycznych nie istnieje żaden taki byt jak Bóg ani sfera bytu, która wykraczałaby poza świat fizyczny. Istnieją tylko materialne substancje i procesy oraz ich wytwory. Z kolei naturaliści metodologiczni mogą, ale nie muszą wierzyć w prawdziwość naturalizmu metafizycznego, utrzymują jednak, że w obrębie nauki nie można odwoływać się do przyczyn transcendentnych. Oznacza to, że sposób prowadzenia badań naukowych w ramach naturalizmu metodologicznego niczym nie różni się od tego, jaki obowiązywałby, gdyby prawdziwy był naturalizm metafizyczny.

W opinii niektórych zasada jednostajności przyrody jest równoważna temu ograniczeniu, ponieważ, jak twierdzą, gdyby Boskie interwencje zmieniały bieg zjawisk przyrodniczych, zakłócałoby to regularność przyrody i uniemożliwiało uprawianie nauki. Zobaczymy jednak, że przekonanie to nie jest słuszne, a uniformitaryzm należy wyraźnie odróżnić od naturalizmu metodologicznego.

Określanie zasady jednostajności struktury przyczynowej przyrody mianem „naturalizmu metodologicznego" jest według mnie poważnym błędem. W kontekście toczącej się dziś dyskusji filozoficznej stosowanie takiej terminologii prowadzi do zamętu pojęciowego, a także utrudnia zarówno wyjaśnienie, na czym polega błędność i negatywny wpływ obecnych koncepcji naukowości, jak i naprawienie tej sytuacji. Robert Bishop, w artykule „God and Methodological Naturalism in the Scientific Revolution and Beyond" [Bóg i naturalizm metodologiczny w czasach rewolucji naukowej i później], ${ }^{2}$ przychylniej odnosi się do terminu „naturalizm metodologiczny”. Podejmuje heroiczną próbę odkupienia „naturalizmu metodologicznego", łącząc go z ujęciem nauki charakterystycznym dla czasów „rewolucji naukowej” oraz oddzielając od współczesnych koncepcji, które obsadzają tę formę naturalizmu w roli metodologicznej służebnicy naturalizmu metafizycznego. Wobec tego wydaje się, że jego koncepcja „naturalizmu metodologicznego" nie odbiega dalece od tego, co rozumiem przez „uniformitaryzm”. Rozbieżność między nami może być w większej mierze natu-

\footnotetext{
${ }^{2}$ Por. Robert Bishop, „God and Methodological Naturalism in the Scientific Revolution and Beyond”, Perspectives on Science and Christian Faith 2013, vol. 65, no. 1, s. 10-23.
} 
ry semantycznej niż rzeczowej, uważam jednak, że próba rehabilitacji „naturalizmu metodologicznego", polegająca na pozbawieniu tego terminu jego dominującego współcześnie znaczenia i połączeniu go z dawnym rozumieniem naukowości, prowadzi donikąd. Jest to termin współczesny i nie funkcjonował on w świadomości uczonych przed końcówką dwudziestego wieku, natomiast obecnie jego dominujące znaczenie jest dokładnie takie, jakie mu przypisałem. Moim zdaniem najlepiej będzie pozostawić znaczenie, którego już nabrał, a na określenie poszukiwanej koncepcji metodologii naukowej użyć zupełnie innego i jednocześnie historycznie trafnego terminu — uniformitaryzm.

Ten ostatni termin także był przedmiotem pewnych kontrowersji. Większość z nich dotyczyła jednak literatury kreacjonistów młodej Ziemi, a w książce Battle of the Beginnings [Batalia o początki] Del Ratzsch umiejętnie wykazał, że w literaturze tej błędnie pojmowano termin ,uniformitaryzm”. ${ }^{3}$ Nawet w ramach klasycznego uniformitaryzmu (Lyella) uznawano, że lokalne zjawiska geologiczne (erupcje wulkanów, trzęsienia ziemi, powodzie, lawiny błotne i tym podobne) miały katastroficzne konsekwencje na skalę geologiczną i paleontologiczną. Występowanie katastrof $\mathrm{w}$ historii przyrody nie stoi bynajmniej w sprzeczności z klasycznym uniformitaryzmem. Co jednak istotniejsze, współczesny uniformitaryzm idzie dalej niż klasyczny, dopuszcza bowiem możliwość katastrof globalnych, jak w wypadku wyginięcia dinozaurów. Przyjmuje też, że tempo oraz nasilenie procesów geologicznych i kosmologicznych mogą ulegać i ulegały zmianie. Tym sposobem z założenia rzeczowego (substantive) uniformitaryzm przekształcił się w założenie metodologiczne, mówiące o tym, na jakie przyczyny można powoływać się w wyjaśnianiu przyczynowej struktury przyrody.

Zgodnie z normatywnym postulatem współczesnego uniformitaryzmu wyjaśnienia geologiczne czy — ogólnie — naukowe sprowadzają się do opisu jednostajnych regularności przyrodniczych lub stanowią ich ekstrapolacje. I właśnie taką ideę jednostajności mam na myśli: Wszechświat ma jednostajną, dającą się badać strukturę przyczynową, stanowiącą trwałą podstawę dla eksperymentów, obserwacji i hipotez naukowych. Jak się ponadto przekonamy, ta koncepcja jed-

\footnotetext{
${ }^{3}$ Por. Del Ratzsch, The Battle of Beginnings: Why Neither Side Is Winning the CreationEvolution Debate, InterVarsity Press, Downers Grove, Illinois 1996, s. 47-53.
} 
nostajności jest $w$ petni zgodna $z$ naukowa teoria inteligentnego projektu i dla niej użyteczna, teoria ta kieruje się bowiem zasadami uniformitaryzmu.

Chociaż zdaję sobie sprawę, że być może zanadto wdaję się w szczegóły, chciałbym podkreślić, że istnieje szereg istotnych powodów, by w kontekście chrześcijańskim posługiwać się terminem uniformitaryzm, a nie naturalizm metodologiczny. Ponieważ pierwszy z tych powodów związany jest ze sposobem, $\mathrm{w}$ jaki pojmuje się działanie opatrznościowe w przyrodzie, więc najpierw scharakteryzuję dwa ujęcia takiego działania, które zdominowały dyskusję teologiczną. Pierwszym i najpopularniejszym ujęciem jest tomistyczna koncepcja przyczynowości wtórnej, drugim - okazjonalizm. Zgodnie z koncepcją tomistyczną każda substancja materialna została stworzona przez Boga i obdarzona właściwymi sobie zdolnościami sprawczymi. Udział Boga w zwykłym następstwie zdarzeń przyrodniczych polega tylko na tym, że stanowi on ostateczną czy pierwszą przyczynę. Bóg podtrzymuje $\mathrm{w}$ istnieniu substancje materialne wraz z ich własnościami, by mogły one odgrywać rolę przyczyn wtórnych. Substancje te są środkami zwykłej aktywności Boga w świecie, działając niezależnie jako aktywne, wtórne przyczyny sprawcze. W myśl okazjonalizmu natomiast Bóg stanowi jedyną przyczynę sprawczą wszystkiego, co wydarza się w sferze Wszechświata niepodlegającej wpływowi stworzonych istot czujących — takich jak normalnie funkcjonujący ludzie — które same mogą inicjować podtrzymywane przez Boga łańcuchy przyczynowe. Krótko mówiąc, w świetle okazjonalizmu bezosobowa przyroda nie ma żadnych czynnych lub biernych zdolności sprawczych, lecz każdy przejaw przyczynowości w świecie nieożywionym stanowi okazję dla bezpośredniego działania Boga — regularność przyrody jest w istocie regularnością Boskiej aktywności.

Dlaczego więc chrześcijanie powinni preferować nie naturalizm metodologiczny, lecz uniformitaryzm? Po pierwsze, jak już wskazałem, założenie jednostajności przyczynowej struktury przyrody to nie to samo, co założenie nienaruszalności przyczyn naturalnych. To drugie założenie mówi o naturze przyrody coś, czego nie mówi pierwsze. Jeżeli, jak wierzy większość chrześcijan, przyczynowa struktura przyrody ma ontyczną podstawę bądź w aktywnym podtrzymywaniu przyczyn wtórnych przez Boga, bądź w bezpośrednim działaniu Bożym, to struktura ta ma należyte ugruntowanie nie w przyczynowości naturalnej, lecz nadnaturalnej. A jeśli - jak utrzymują okazjonaliści — podstawowym 
źródłem regularności przyrody jest bezpośrednie działanie Boga, to w przyrodzie nieożywionej nie istnieje nic takiego, jak przyczynowość naturalna. Wrócimy do tego tematu później.

Po drugie, termin „naturalizm metodologiczny” został ukuty niedawno, w związku z czym łączenie go z dawnym rozumieniem naukowości jest anachroniczne i powoduje nieporozumienia. Wprawdzie możliwym znaczeniem słowa „naturalista” nadal jest „ten, kto bada przyrodę i jej rozwój”, ale termin „naturalizm” nie ma zbliżonego znaczenia w dyskusjach toczonych dziś na gruncie nauki lub filozofii nauki. W ujęciu, które zdominowało dyskusję filozoficzną na przestrzeni większej części minionego stulecia, „naturalizm” oznacza negację nadnaturalizmu. Na płaszczyźnie metafizycznej jest to doktryna głosząca, że nie istnieje sfera transcendentna, że Boga nie ma, a jedyne, co istnieje, to przyroda, czyli całkowita suma obiektów i przyczyn fizycznych. Na płaszczyźnie metodologicznej oznacza to zgodę, by dla celów naukowych odrzucić przyczynowość nadnaturalną i traktować przyrodę, jak gdyby była zamkniętym systemem przyczyn i skutków - krótko mówiąc, jest to przyjęte dla celów naukowych metodologiczne założenie przyczynowego domknięcia fizycznego Wszechświata. Niektórzy mogą argumentować, że nie takie znaczenie chciano pierwotnie nadać temu terminowi i nie należy narzucać nowego znaczenia tym, którzy chcieliby posługiwać się owym określeniem w zgodzie z jego pierwotną treścią. Przy całym szacunku do tego stanowiska mam jednak odmienne zdanie. Stosowanie terminu „naturalizm metodologiczny” na oznaczenie zgodnej z myślą chrześcijańską koncepcji jednostajności przyrody to w obecnych warunkach zabieg zupełnie niewłaściwy: termin ten standardowo oznacza teraz ni mniej, ni więcej aniżeli zalożenie przyczynowego domknięcia fizycznego Wszechświata przyjęte dla celów naukowych i nie da się już tego cofnąć. Nie można już zmienić tego, że zwolennicy naturalizmu metafizycznego i filozoficznego rozumieją ten termin w sposób, jaki opisałem wyżej.

Co więcej, w dzisiejszych dyskusjach taki sens przypisuje mu także wielu spośród tych, którzy nie są zwolennikami naturalizmu filozoficznego. Przykładowo Nancey Murphy określa nawet tę zasadę przyczynowego domknięcia mianem „metodologicznego ateizmu” i mimo że jest teistką, uznaje ją za zasadne 
metanaukowe ograniczenie. ${ }^{4}$ Alvin Plantinga, Del Ratzsch, Stephen Meyer, William Dembski i wielu innych nie traktuje naturalizmu metodologicznego jako zasady, która rządzi praktyką naukową, ale oni również przypisują mu wskazaną przeze mnie treść - niektórzy $\mathrm{z}$ nich nawet na łamach niniejszego czasopisma [Perspectives on Science and Christian Faith]. Nie ma zatem zbyt wielkiej nadziei na to, że we współczesnym kulturowym milieu da się odkupić termin „,naturalizm metodologiczny”, nadając mu na przykład znaczenie „,metodologicznego założenia jednostajności przyrody”. Nie widzę też sensu podejmowania takiej próby, termin ten bowiem w naturalny sposób skojarzony jest z naturalizmem filozoficznym, a nie uniformitaryzmem.

Wreszcie, gdy naturalizm metodologiczny rozumie się jako przyjęte dla celów naukowych założenie, że rzeczywistość fizyczna jest przyczynowo domknięta - wziąwszy przy tym pod uwagę, że dokładnie $w$ takim znaczeniu termin ten jest używany obecnie - to twierdzenie, iż właśnie to założenie jest koniecznym i integralnym elementem praktyki naukowej, należy poddać krytyce $\mathrm{i}$ - w moim przekonaniu — odrzucić. Mógłbym, podobnie do innych chrześcijańskich uczestników tej dyskusji, utrzymywać, że naturalizmowi metodologicznemu należy przypisywać treść bardziej zbliżoną do uniformitaryzmu i że powinien on być do przyjęcia dla chrześcijan. W takim wypadku koncepcja naturalizmu metodologicznego, która zdominowała współczesną dyskusję, nie wzbudzałaby jednak sprzeciwu, na jaki zdecydowanie zasługuje. Jako chrześcijanie musimy odrzucić nie tylko naturalizm metafizyczny, ale również jego metodologiczną służebnicę.

Niektórzy w dalszym ciągu mogą sądzić, że panuje tu zamieszanie pojęciowe, któremu — jak zauważył jeden z recenzentów mojego artykułu — można zaradzić, przyjmując następujący sposób rozumowania:

\footnotetext{
${ }^{4}$ Murphy wyjaśnia: „[...] istnieje coś, co możemy nazwać metodologicznym ateizmem, który $\mathrm{z}$ definicji podzielają wszystkie nauki przyrodnicze [...] Jest to po prostu zasada, zgodnie z którą wyjaśnienia naukowe należy formułować, odwołując się do bytów i procesów naturalnych (nie zaś nadnaturalnych)” (Nancey Murphy, „Phillip Johnson on Trial: A Critique of His Critique of Darwin", Perspectives on Science and Christian Faith 1993, vol. 45, no. 1, s. 26-36). Krytyczną dyskusję na temat możliwości uznania „naturalizmu metodologicznego” i „,metodologicznego ateizmu" za terminy stosowne dla określenia chrześcijańskiego rozumienia nauki obejmuje druga część eseju Lorena HaArsmy, „Christianity as a Foundation for Science”, http://www.asa3.org/ ASA/education/origins/mn-lh.htm.
} 
[naturalizm metodologiczny stanowi] ograniczenie nałożone na te teorie i określone zespoły danych, które klasyfikuje się jako naukowe, [nie zaś] założenie przyczynowego domknięcia świata fizycznego [...] Tak więc mogę na przykład uważać, że Bóg zachowuje świat $\mathrm{w}$ istnieniu i zarazem działa $\mathrm{w}$ nim, dokonując specjalnych aktów stwórczych, przez co świat nie jest przyczynowo domknięty. Jednak nie przecząc temu, mogę też sądzić, że rozsądnie jest wystrzegać się teorii naukowych, które powołują się na Boga lub inne nadnaturalne byty. ${ }^{5}$

Nie mamy tu jednak do czynienia z zamieszaniem pojęciowym. Nie twierdziłem, że naturalizm metodologiczny stawia wymóg przyjęcia metafizycznego założenia, że świat jest domknięty przyczynowo. Co więcej, moja charakterystyka naturalizmu metodologicznego jest bezpośrednią logiczną konsekwencją ograniczeń, jakie naturalizm metodologiczny (w ujęciu recenzenta) nakłada na to, co uznawane jest za „naukowe”. Naturalizm metodologiczny to warunkowe założenie, które nie przesądza o tym, że domknięcie przyczynowe jest faktem metafizycznym, lecz dla celów naukowych abstrahuje od przyczyn transcendentnych. Innymi słowy, naturalizm metodologiczny, jako zasada majaca na celu poszukiwanie wyjaśnień naukowych, wyklucza odwołania do przyczyn transcendentnych. Jakie ma to jednak konsekwencje? Otóż takie, że formułując wyjaśnienia naukowe, należy postępować tak, jak gdyby Wszechświat był układem przyczynowo domkniętym. Dlaczego? Po prostu dlatego, że jedynymi wyjaśnieniami dopuszczalnymi $w$ obrębie (tak wąsko rozumianej) nauki są wyjaśnienia naturalistyczne. To umowne ograniczenie nie wyklucza możliwości „nienaukowych" wyjaśnień powołujących się na przyczyny transcendentne, ale implikuje, że nie ma wyjaśnień ,naukowych” innych niż naturalistyczne. W związku z tym, chociaż moja definicja naturalizmu metodologicznego jako przyjętego dla celów naukowych metodologicznego założenia przyczynowego domknięcia Wszechświata może być niewygodna dla chrześcijańskich zwolenników naturalizmu metodologicznego, to jest ona metodologicznie równoważnym przeformutowaniem ograniczenia zawartego $\mathrm{w}$ ich definicji. Jeśli na to przystaniemy, wówczas otworzy się pojęciowa droga dla argumentu, że uniformitaryzm i naturalizm metodologiczny to dwa różne pojęcia i że — z perspektywy chrześcijańskiej — pierwsze lepiej określa praktykę naukową.

\footnotetext{
${ }^{5}$ Komentarz anonimowego recenzenta.
} 
Zgodnie z zasadą uniformitaryzmu zakłada się, że przyroda zachowuje się w sposób regularny, co świadczy o jej obiektywnej strukturze przyczynowej, w której obecnie działające przyczyny można rzutować na przeszłość w celu wyjaśnienia historycznego rozwoju świata fizycznego oraz na przyszłość, aby móc dokonywać przewidywań i utrzymywać kontrolę. Krótko mówiąc, uniformitaryzm obejmuje proces wnioskowania o przeszłych przyczynach na podstawie obecnie obserwowanych skutków przy założeniu, że podstawowe regularności przyczynowe świata nie uległy zmianie w czasie. Natomiast naturalizm metodologiczny wyklucza z rozważań naukowych przyczyny nadnaturalne, czyli przyczyny wykraczające poza sferę fizyczną: w kontekście wyjaśnień naukowych działanie Boga (lub jakiejkolwiek innej przyczyny transcendentnej) nie może być uznane za możliwe wyjaśnienie w żadnym badaniu naukowym kropka. Przy takiej definicji zasadę tę być może lepiej byłoby nazywać metodologicznym ateizmem - i tak właśnie określa ją Nancey Murphy — zachowamy jednak standardową terminologię.

Sądzę, że w świetle dotychczasowych rozważań dostrzegamy już, że metodologiczne założenie przyczynowego domknięcia Wszechświata, które stanowi integralny element naturalizmu metodologicznego, jest zarówno niezgodne z przekonaniami chrześcijan na temat metafizycznej podstawy regularności świata fizycznego, jak i zbędne z perspektywy praktyki naukowej. Ponadto naturalizm metodologiczny nie dysponuje metafizycznym zapleczem do wyjaśnienia konstytucji i przyczynowej integralności świata fizycznego (obszerniejszą argumentację na rzecz tej tezy przedstawiam w innych publikacjach ${ }^{6}$ ). Tym samym jest on nie tylko zbędny z punktu widzenia praktyki naukowej, ale stanowi też przeszkodę dla właściwego zrozumienia przyrody, gdyż wymaga obiektywnego wypaczenia tego, w jaki sposób świat fizyczny faktycznie zachowuje swoją trwałą budowę i regularność przyczynową. Materialna przyczynowość sprawcza nie jest filarem wyjaśniania naukowego, co w opinii historyków nauki rzekomo miało zostać uznane od czasów Rewolucji Naukowej, lecz fenomenolo-

\footnotetext{
${ }^{6}$ Por. przygotowywany przez mnie esej: „Quantum Theory, Sufficient Causation, and the Theistic Foundations of Natural Science”; równie ważny jest inny mój esej: „A Quantum-Theoretic Argument against Naturalism", w: Bruce L. Gordon and William A. Dembsкi (eds.), The Nature of Nature: Examining the Role of Naturalism in Science, ISI Books, Wilmington, Delaware 2011, s. 179-214.
} 
gicznym artefaktem przyczynowości formalnej (zaprojektowania w myślach) i celowej (rozmyślnej realizacji), które stanowią jej metafizyczną podstawę. Pomimo że siedemnastowieczni chrześcijańscy zwolennicy filozofii mechanistycznej interesowali się głównie mechanizmami działającymi na zasadzie bezpośredniego kontaktu, można obiektywnie stwierdzić, że w swoim ujęciu tych mechanizmów, które uważali za zaprojektowane, zachowali oni zarówno arystotelesowskie przyczyny formalne, jak też arystotelesowskie przyczyny celowe, uznając, że ten mechaniczny projekt służy zamierzonemu celowi w stworzonym porządku rzeczy. Wskazuje na to wiele wypowiedzi z tego okresu, ale przytoczę tylko jeden ustęp pochodzący z pism naukowca Roberta Boyle'a (1627-1691):

Gdy [...] widzę niezwykły zegar, uderza mnie, w jak uporządkowany sposób każde kółko i inne części wykonują swoje ruchy, z jaką — mogłoby się zdawać - jednomyślnością zmawiają się, by wskazywać godzinę i realizować cele rzemieślnika. Nie uważam, by którekolwiek z tych kółek lub innych części, czy też cały mechanizm był obdarzony rozumem, lecz dostrzegam rozum zegarmistrza, który tak umiejętnie wykonał to urządzenie. Kontemplując zatem działanie tych licznych stworzeń, z których składa się świat, nie uznaję, że nieożywione ich rodzaje lub cały ogromny mechanizm działał rozumnie czy celowo, lecz podziwiam i chwalę mądrego autora, który dzięki swej zdumiewającej pomysłowości z tak wielką łatwością potrafi tworzyć skutki wymagające tak ogromnej liczby kolejno działających, zgodnych przyczyn. ${ }^{7}$

Jeśli się na to zgodzimy, będzie to także odpowiedź na zarzuty, że odwoływanie się do transcendentnej przyczynowości inteligentnej jest nienaukowe $\mathrm{z}$ tego powodu, że nie można podać mechanizmu jej działania, a materialne mechanizmy sprawcze sprowadza się jedynie do fenomenologicznych artefaktów nieredukowalnej i podstawowej w sensie metafizycznym przyczynowości istoty transcendentnej, która przejawia się zarówno $\mathrm{w}$ działaniu regularnym (prawopodobnym), jak i wyjątkowym (mam tu na myśli wprowadzanie złożonej wyspecyfikowanej informacji). Taki stan rzeczy oznaczałby również, że ostateczna jednostajność przyrody nie jest jej cechą wewnętrzną, lecz zewnętrzna i transcendentnie na nią nałożoną. Co więcej, jeśli w myśl teorii kwantów przyjmiemy, że materialna przyczynowość sprawcza jest niewystarczająca podstawą eksplanacyjną dla wszystkich zjawisk fizycznych, to milcząco uznamy również, że obserwowana przez nas jednostajność nałożona jest na przyrodę przez transcen-

\footnotetext{
${ }^{7}$ The Works of the Honourable Robert Boyle, 5 volumes, vol. 1, London 1744, s. 447.
} 
dentną przyczynę inteligentną nie tylko w sposób ostateczny, ale także bezpośredni i niezmienny. Jak wnikliwie zauważył (choć, niestety, z niezbyt wielką przychylnością) jeden z recenzentów czasopisma Perspectives on Science and Christian Faith, przyjęcie tej perspektywy byłoby równoznaczne z tym, że nasze teorie naukowe, zwłaszcza gdy postulują ogólne prawa, nie opisują jednostajności samej przyrody, lecz jednostajność Boskiego działania (lub, jak się wyraził, formułowalibyśmy „ogóle prawa opisujące zachowanie Boga”). I rzeczywiście tak jest (por. Dz 17:28; Kol 1:17 i tak dalej).

Nietrudno więc dostrzec, że naturalizm metodologiczny nie jest koniecznym założeniem należytej praktyki naukowej i mimo że nie wyklucza możliwości prowadzenia pozanaukowych rozważań o działaniu Boskiej przyczynowości, to i tak zasadniczo przeczy chrześcijańskiemu pojmowaniu funkcjonowania przyrody. Naturalizm metodologiczny nie jest stanowiskiem równie mocnym, jak naturalizm metafizyczny, ponieważ wykluczając przyczynowość transcendentną z wyjaśniania naukowego, nie wyklucza możliwości, że Bóg istnieje i może działać w historii: naturalizm metodologiczny zakazuje tylko rozważania tej możliwości w kontekście praktyki naukowej.

Naturalista metodologiczny może uznawać możliwość zachodzenia cudów, postrzegając je jako specjalne działania Boga, które dla określonych celów zmieniają bieg zdarzeń przyrodniczych, ale leżą poza właściwym zasięgiem rozważań naukowych. Jednak oprócz argumentu, że jeśli Bóg działa w historii, to taki zakaz uniemożliwia nauce odkrycie prawdziwej przyczyny badanych skutków, jeszcze inny, znacznie głębszy powód przemawia za tym, że naturalizm metodologiczny znajduje się $\mathrm{w}$ relacji zasadniczego napięcia $\mathrm{z}$ chrześcijańskim pojmowaniem przyczyny regularności przyrody. Przypuśćmy - wzorem chrześcijan — że właściwym wyjaśnieniem regularności przyrody jest regularność Boskiej aktywności. Innymi słowy, przypuśćmy, że przyroda zachowuje się w sposób regularny bądź z powodu koniecznej roli Boga w podtrzymywaniu istnienia oraz wystarczalności przyczyn wtórnych, bądź dlatego, że regularność przyrody po prostu jest regularnością bezpośredniego działania Boga. O pierwszej możliwości mówił Tomasz z Akwinu, a przyjęto ją również w Westminsterskim Wyznaniu Wiary (rozdział V, część 2). Drugą możliwość zakłada okazjonalizm, zgodnie z którym Bóg stanowi jedyna przyczynę sprawczą wszystkiego, co wydarza się w sferze Wszechświata niepodlegającej wpływowi 
stworzonych istot moralnych — takich jak normalnie funkcjonujący ludzie które same mogą inicjować podtrzymywane przez Boga łańcuchy przyczynowe. Okazjonalizm - pogląd preferowany przeze mnie z uwagi na ustalenia teorii kwantów, ale nie ma tu miejsca na szczegółowe omówienie tej kwestii ${ }^{8}$ - to ujęcie opatrzności Bożej sformułowane w różny sposób przez takich filozofówteologów jak George Berkeley i Jonathan Edwards.

Teraz należy poczynić prostą uwagę: historycznie rzecz biorąc, ortodoksyjne chrześcijańskie rozumienie podstawowej roli Boga w istnieniu przyrodniczych regularności jest wprost przeciwstawne idei przyczynowego domknięcia. Przyroda jest regularna nie dlatego, że jest zamknięta na działanie Boga, lecz dlatego (i tylko dlatego), że Boska przyczynowość działa w świecie. W świetle ortodoksyjnego chrześcijańskiego ujęcia to właśnie brak domknięcia przyczynowego, a tym samym fatszywość naturalistycznych założeń metodologicznych, zapewnia metafizyczną podstawę dla regularności przyrody i możliwości uprawiania nauki. Istnienie i działanie Boga nie wyklucza nauki, lecz stanowi podstawę samej możliwości jej uprawiania. Co więcej, skoro koniecznym warunkiem praktyki naukowej jest sama regularność przyrody, nie zaś brak przyczynowości nadnaturalnej, która stanowi jej podstawę, to naturalizm metodologiczny jest założeniem równie bezzasadnym, co heterodoksyjnym. Jako chrześcijanie nie tylko możemy, ale też powinniśmy się bez niego obejść. Uniformitaryzm jest wystarczający.

Kilkakrotnie nawiązałem w tym omówieniu do teorii kwantów i pozwolę sobie teraz na dość krótki, choć ważny komentarz. Chociaż teoria kwantów dostarcza bardzo użytecznych opisów matematycznych, które umożliwiają formułowanie niewiarygodnie dokładnych przewidywań empirycznych, to nie zapewnia absolutnie żadnego wyjaśnienia, dlaczego rzeczywistość fizyczna może być zgodna z takimi opisami ani dlaczego obserwujemy jakiś konkretny efekt kwantowy. Krótko mówiąc, nie pozwala nam zrozumieć (ani nie wskazuje żadnego realnego mechanizmu), jak świat naprawdę funkcjonuje. Próby wskazania „mechanizmu", sprowadzające się do postulowania lokalnych zmiennych ukrytych (deterministycznych bądź stochastycznych) i mające na celu zapewnienie takiego wyjaśnienia, nie prowadzą do wyników przeczących kwantowo-mechanicz-

\footnotetext{
${ }^{8}$ Por. moje eseje cytowane w przyp. 6.
} 
nemu łamaniu nierówności Bella. Wygląda więc na to, że - o ile nie zaprzeczymy wynikom eksperymentów - charakterystyczne zjawiska kwantowo-mechaniczne nie maja fizycznego wyjaśnienia. Jeżeli zatem mają w ogóle jakieś wyjaśnienie, to ma ono charakter wyjaśnienia metafizycznego, które wykracza ponad to, co fizyczne. ${ }^{9}$

Jaki ma to wpływ na omówione wyżej dwa ujęcia działania opatrznościowego? Podstawą tomistycznego modelu opatrzności, który postuluje przyczynowość wtórną, jest konieczność przyrodnicza mająca stanowić wrodzoną cechę stworzonych bytów działających jako niezależne przyczyny wtórne. Okazuje się on nieadekwatny w dziedzinie kwantów między innymi z tego względu, że nie oferuje pełnego ujęcia fizycznej przyczynowości. Mimo że na zachowanie układów fizycznych nałożone są probabilistyczne ograniczenia, to na czysto fizycznym poziome opisu kwantowego większość jednostkowych zjawisk kwantowych nie ma fizycznej racji dostatecznej, a więc nie może być skutkiem działania przyczynowości wtórnej.

Drugim ujęciem Boskiej opatrzności jest okazjonalizm, który preferuję z uwagi na ustalenia teorii kwantów. Jak wpisuje się on w naszą obecną dyskusję? Na przykład w wypadku nielokalnych korelacji kwantowych, które ze względu na ograniczenia relatywistyczne nie mają żadnego fizycznego wyjaśnienia, okazjonalizm zapewnia metafizyczny kontekst, który rozwiązuje pewne ontologiczne zagadki: wspomniane korelacje mają wspólną niefizyczna przyczynę, czyli bezpośrednie działanie Boga polegające na podtrzymywaniu reprezentowanych przez te korelacje regularności przyrodniczych. Mówiąc zwięźlej, Bóg jest wysoce aktywną (jedyną sprawczą) przyczyną kwantowych korelacji i w istocie wszystkich zjawisk kwantowych, które konstytuują nasze doświadczenie świata. Okazjonalizm oferuje również rozwiązanie problemu braku lokalizacji czasoprzestrzennej oraz substancjalności pojedynczych nieobserwowanych kwantów. Skoro nie dysponują one żadnymi czynnymi lub biernymi zdolnościami sprawczymi, to podstawowe składniki „materialnego" świata nie mogą utrzymywać się w istnieniu jako quasi-zlokalizowane zjawiska. Ich istnienie zależne jest od bezpośredniego działania Boga, a więc otrzymują istnienie jedynie

\footnotetext{
${ }^{9}$ Także tym razem obszerniejsze uzasadnienie tego oraz innych twierdzeń z kolejnych czterech akapitów znajdzie czytelnik w pracach cytowanych w przyp. 6 .
} 
jako fenomenologiczne struktury umieszczone w kontekście interaktywnych zdarzeń, które po dokonaniu pomiaru są empirycznie zgodne ze statystycznymi prawidłowościami przewidywanymi przez teorię kwantów. Prowadzi to do obrazu Boga, który nie tylko stale podtrzymuje stworzenie w istnieniu, lecz także nieustannie stwarza je ex nihilo. Jest to więc argument za słusznością doktryny creatio continua. Zapewne ta sama metafizyka wyłoniłaby się z teorii kwantowej grawitacji, która kwantuje czas fizyczny w skali Plancka. Mamy więc w tym wypadku spójność, aczkolwiek uzasadnienie jest pod pewnymi względami inne.

Jakie, patrząc z szerszej perspektywy, konsekwencje niesie uzmysłowienie sobie, że potrzebne jest wyjaśnienie metafizyczne, nie zaś tylko fizyczne? Stosując metafizyczną odmianę wnioskowania abdukcyjnego, można zrazu uznać, że istnienie porządku przyrodniczego, który daje ontologiczne ugruntowanie zasadzie uniformitaryzmu - metodologicznemu założeniu regularności w strukturze przyczynowej świata, które jest niezbędne dla możliwości uprawiania nauki - znajduje swoje najlepsze i być może jedyne uzasadnienie w metafizyce teistycznej. Nie powinno więc dziwić, że to teistyczne przekonanie dało dawniej potężny bodziec do rozwoju nauki, ${ }^{10}$ ponieważ nadal stanowi ono ontologiczną podstawę, dzięki której praktyka naukowa ma największy metafizyczny i poznawczy sens. Naturalizm metodologiczny jest zatem nie tylko zbędny w praktyce naukowej, ale też na zawsze uniemożliwia przyjęcie metafizycznej podstawy, w świetle której badania naukowe można zasadnie uznać za działalność dążącą do prawdy. Na zawsze wyklucza także możliwość obiektywnego naukowego ustalenia, czemu naprawdę (i dlaczego) zawdzięczamy spójność świata, w którym egzystujemy.

To transcendentny inteligentny projekt wyjaśnia regularność przyrody i zapewnia metafizyczne uzasadnienie uniformitaryzmowi w nauce. Przyroda jest regularna, ale właśnie $z$ powodu transcendentnej przyczynowości, nie zaś pomimo niej. W tym metafizycznym ujęciu wszystko, co się wydarza, jest przez Boga albo zamierzone, albo - jeśli uwzględnimy skutki działania istot stworzonych

\footnotetext{
${ }^{10}$ Rzetelne i zajmujące naukowe opracowanie tego tematu można znaleźć w: James Hannam, The Genesis of Science: How the Christian Middle Ages Launched the Scientific Revolution, Regnery, Washington, DC. 2011.
} 
— dopuszczone. ${ }^{11}$ Akceptacja tego stanu rzeczy umożliwia niebudzące zastrzeżeń rozszerzenie zasady uniformitaryzmu na przyczynowość inteligentną. Możemy zatem umieścić w nowym, ogólnym kontekście argument po raz pierwszy wyartykułowany w wyszukanej (i nieteologicznej) postaci przez Stephena Meyera. ${ }^{12} \mathrm{~W}$ ramach rozumowania zgodnego z zasadami uniformitaryzmu przeszłe przyczyny wywodzone są z teraźniejszych skutków przy założeniu, że przyczynowa struktura świata jest zawsze taka sama, co umożliwia dokonywanie wiarygodnych wnioskowań. Pod tym względem mamy niezwykle jasne pojęcie na temat tego, co może zdarzyć się w regularnym biegu zjawisk przyrodniczych, który stanowi trwałe tło ludzkiej aktywności. Następnie możemy dokonać porównania ze zdarzeniami wykraczającymi poza regularny bieg zjawisk przyrodniczych i wymagającymi szczególnego, ukierunkowanego działania przyczyny inteligentnej. Struktury i procesy cechujące się złożoną wyspecyfikowaną informacją w stopniu przekraczającym wszechświatowe granice prawdopodobieństwa ${ }^{13}$ są notorycznie i bez wyjątku związane $\mathrm{z}$ działaniem inteligencji. Jest to jeden z elementów jednostajności, jaką obserwujemy w przyczynowej strukturze świata $\mathrm{i}$ - jako nieodłączna część wypływających z uniformitaryzmu założeń

\footnotetext{
${ }^{11}$ Właśnie to ujęcie, a nie naturalizm metodologiczny, Boyle, Newton i niemal wszyscy siedemnasto- i osiemnastowieczni (a także żyjący wcześniej) fillozofowie przyrody uznaliby za właściwą podstawę badania regularności przyrody.

${ }^{12}$ Por. m.in. następujące publikacje Stephena C. Meyera: Of Clues and Causes: A Methodological Interpretation of Origin of Life Studies, rozprawa doktorska, Cambridge University 1990; Signature in the Cell: DNA and the Evidence for Intelligent Design, HarperOne, San Francisco, California 2009. Najnowszym opracowaniem jest obszerny zbiór artykułów: Robert J. Marks II, Michael J. Behe, William A. Dembski, John C. Sanford, and Bruce L. Gordon (eds.), Biological Information: New Perspectives, World Scientific, New Jersey - London - Singapore - Beijing - Shanghai - Hong Kong - Taipei - Chennai 2013.

(Przyp. tłum.) Istnieje polski przekład pięciu pierwszych rozdziałów Signature in the Cell Stephena C. Meyera: „DNA, Darwin i wrażenie projektu”, przeł. Małgorzata Gazda, Problemy Genezy 2012, t. XX, s. 175-195; „Ewolucja tajemnicy”, przeł. Małgorzata Gazda, Problemy Genezy 2012, t. XX, s. 196-220; „Podwójna helisa”, przeł. Małgorzata Gazda, Problemy Genezy 2012, t. XX, s. 221-244; „Podpis w komórce”, przeł. Małgorzata Gazda, Problemy Genezy 2012, t. XX, s. 245-268; „Molekularny labirynt”, przeł. Małgorzata Gazda, Problemy Genezy 2012, t. XX, s. 269-290.

${ }^{13} \mathrm{Z}$ technicznymi szczegółami ustalania wszechświatowej granicy prawdopodobieństwa można zapoznać się np. w: Seth Lloyd, „Computational Capacity of the Universe”, Physical Review Letters 2002, vol. 88, http://arxiv.org/pdf/quant-ph/0110141v1.pdf, doi:10.1103/PhysRev Lett.88.237901.
} 
nauki - mieści się, pod względem metodologicznym i rzeczowym, w zakresie badań naukowych. W szerszym metafizycznym kontekście działania opatrznościowego dostrzegamy zatem, że Bóg odpowiada zarówno za regularność przyrody, jak $i$ za pewne wyjątkowe zdarzenia, ale związany z nimi sposób Boskiego działania (regularny lub wyjątkowy) jest, jak wskazaliśmy, rozpoznawalny na podstawie swoich charakterystycznych skutków.

Idea, że elementy przyrody najlepiej można ujmować w modele przy wykorzystaniu narzędzi matematycznych opisujących procesy, których cel jest określony przed jego osiągnięciem, lub struktury będące rezultatem tych procesów, jest wyjątkowo sensowna w kontekście teistycznym i w pełni zgodna $\mathrm{z}$ niezbędnymi dla nauki założeniami uniformitaryzmu. Jeśli odrzucimy fałszywe ograniczenie naturalizmu metodologicznego i będziemy w zamian polegać na zasadzie uniformitaryzmu, która umożliwia rozpoznawanie obiektywnych i regularnych cech przyczynowości inteligentnej na podstawie powtarzalnego doświadczenia, stanie się całkowicie jasne, że przyroda przejawia wyrażalną ilościowo teleologię, a badanie tego zagadnienia ma charakter ściśle naukowy. Tego właśnie, w dużej mierze, dotyczy matematyczny i badawczy program teorii inteligentnego projektu.

Trzydzieści siedem lat temu Nicholas Wolterstorff rzucił wspólnocie chrześcijańskich uczonych i badaczy takie oto wyzwanie:

Naukę i zwyczajne życie można umieścić na kontinuum ze względu na obecność teorii $i$ czyny dokonywane [w rezultacie wiary w] te teorie. Nad wyraz charakterystyczne dla nauki jest to, że teorie wykorzystywane są do inspirowania programów badawczych i kierowania nimi [...] Każdy, kto ocenia jakąś teorię, żywi pewne przekonania na temat tego, co stanowi akceptowalny rodzaj teorii w odniesieniu do badanego problemu. Nazywamy je przekonaniami kontrolnymi [...] Religijne przekonania chrześcijańskiego uczonego powinny funkcjonować jako przekonania kontrolne w procesie opracowywania i oceniania teorii. Nie jest to zresztą jedyny sposób, w jaki powinny funkcjonować. Przykładowo powinny one służyć pomocą w kształtowaniu jego poglądów na to, dlaczego dysponowanie teoriami jest ważne. Ale to i tak nie wyczerpuje ich funkcji. W każdym razie ich funkcjonowanie jako przekonań kontrolnych jest absolutnie kluczowe dla pracy chrześcijańskiego uczonego [...] Podejmowane przez chrześcijańskich uczonych próby „,połączenia wiary i wiedzy” rzadko jednak inspirują programy badawcze w ramach nauk przyrodniczych. Moim zdaniem jest to oznaka bądź niezdolności dostrzeżenia przez chrześcijańskich uczonych, jak ich religijne przekonania mogą i powinny wpływać na ocenę teorii, bądź słabej wyobraźni. Zwracanie uwagi na 
początku kursu biologii, że cała biologiczna rzeczywistość została stworzona przez Boga, nie inspiruje żadnego biologicznego programu badawczego. Jest to jedynie [...] „umieszczanie w kontekście chrześcijańskim”. [...] Nauka chrześcijańska będzie uboga, licha i niewarta zbytniej uwagi, dopóki chrześcijański uczony nie sformułuje, podporządkowując się swoim autentycznym przekonaniom, teorii prowadzących do obiecujących, interesujących, owocnych, ambitnych linii badań. ${ }^{14}$

Misja chrześcijan uprawiających naukę w roli teoretyków, badaczy terenowych i eksperymentatorów nie powinna być dostosowana do świeckiego modelu badań, który podporządkowany jest założeniom naturalistycznym, lecz winna mieć na celu przekształcenie praktyki naukowej i roli nauki w świecie (por. Rz 12:1-2). Badania w ramach teorii inteligentnego projektu mają zasadniczo taki właśnie transformacyjny charakter. Jako chrześcijanie musimy starać się wykazać, że śniedź naturalizmu metafizycznego i metodologicznego, która osiadła na współczesnej praktyce naukowej, jest głęboko destrukcyjna i nie do przyjęcia na płaszczyźnie intelektualnej. Odpowiedni z historycznego punktu widzenia termin uniformitaryzm lepiej niż naturalizm metodologiczny nadaje się na określenie trafnej koncepcji metodologii naukowej, która umożliwia podążanie za danymi naukowymi, dokądkolwiek one prowadzą, nawet jeśli badania wskazują na transcendentną przyczynowość inteligentną. Jest to właściwe podejście również dlatego, że teistyczny pogląd na świat zapewnia nie tylko naturalne uzasadnienie zakładanego przez naukę porządku w świecie, ale być może także jedyną sensowną metafizyczną podstawę dla oczekiwania, że umysł ludzki będzie w stanie ten porządek pojąć.

\section{Podziękowania}

Chciałbym podziękować Robertowi Bishopowi za zorganizowanie w 2011 roku sympozjum ASA, na którym przedstawiłem pomysły wykorzystane w tym artykule. Wyrazy wdzięczności kieruję też w stronę Rona Numbersa, Kathryn Applegate, Joego Spradleya, Roberta Bishopa (ponownie), Steve'a Dilleya, Steve'a Meyera, Ricka Sternberga, Nancey Pearcey, Roba Koonsa oraz różnych uczestników (zwłaszcza Stewarta Goetza i Toma Tracy) zorganizowanego przez

\footnotetext{
${ }^{14}$ Nicholas Wolterstorff, Reason within the Bounds of Religion, 2nd ed., William B. Eerdmans, Grand Rapids, Michigan 1984, s. 65, 67, 70, 105-106.
} 
Templeton Foundation sympozjum zatytułowanego „Być człowiekiem w świetle teistycznego punktu widzenia”. Prowadziłem z nimi rozmowy luźno lub ściśle związane $\mathrm{z}$ tematem naturalizmu metodologicznego, które przyczyniły się do dopracowania moich poglądów. Chciałbym podziękować również anonimowym recenzentom czasopisma Perspectives on Science and Christian Faith za zachęcenie mnie do jaśniejszego wyrażenia różnych aspektów definicyjnych i polemicznych. Za wszystkie błędy, które mogą kryć się jeszcze w mojej prezentacji $\mathrm{i}$ argumentacji, winę ponoszę wyłącznie ja.

Bruce L. Gordon

\section{In Defense of Uniformitarianism}

\section{Summary}

The practice of science rests on the assumption of dependable regularity in the behavior of the physical world. It presumes that the world has an investigable causal structure and that scientific experimentation, observation, and theorizing provide a reliable pathway to its discernment. This much is not in dispute. What is in dispute is what warrants the metaphysical and methodological assumption - essential to the heuristic utility of science - that nature is uniform in such a way that the present can serve as a key to both the past and the future. This article focuses on the metaphysical foundation and justification for uniformitarian assumptions about nature and argues that they are inconsistent with both metaphysical and methodological naturalism.

Keywords: uniformitarianism, methodological naturalism, metaphysical naturalism, Christian theism, divine providential action, Thomistic secondary causation, occasionalism, quantum theory, transcendent intelligent causation, intelligent design theory.

Slowa kluczowe: uniformitaryzm, naturalizm metodologiczny, naturalizm metafizyczny, teizm chrześcijański, boskie działanie opatrznościowe, tomistyczna koncepcja przyczynowości wtórnej, okazjonalizm, teoria kwantów, transcendentna przyczynowość inteligentna, teoria inteligentnego projektu. 